\title{
Esophagus and Esophagogastric Junction Cancer Pathologic TNM Finding v8
}

National Cancer Institute

\section{Source}

National Cancer Institute. Esophagus and Esophagogastric Junction Cancer Pathologic

TNM Finding v8. NCI Thesaurus. Code C133369.

A pathologic finding about one or more characteristics of esophagus and esophagogastric junction cancer, following the rules of the TNM AJCC v8 classification system. 